\title{
Assessment of Pesticides on Selected Vegetables in Pathanamthitta District.
}

\author{
Shakhila. S. S ${ }^{(1)}$ Keshav Mohan ${ }^{(2)}$
}

\begin{abstract}
The aim of present study was to assess pesticide residues in vegetables in the Pathanamthittadistrict.The concentrations of six pesticides were determined by gas chromatography coupled with mass selective detector (GC-MS) in locally produced vegetables purchased from wholesale markets. A total of 20 samples of four vegetables viz. Pea, snakegaurd, bittergaurd,brinjalwereanalyzed for pesticide residues. The results indicated that none of the samples were contaminated with pesticides. The physico chemical properties of samples from the three locations were analyzed and observed they were very rich in organic carbon content and contains higher percentage of organic matter.
\end{abstract}

Key words: Vegetables, Pesticides, QuEChERS method, Soil

Pesticides are chemicals used to eliminate or control a variety of agricultural pests that can damage crops and livestock and reduce farm productivity. The most commonly applied pesticides are insecticides (to kill insects), herbicides (to kill weeds), rodenticides (to kill rodents) and fungicides (to control fungi, mould and mildew). Of these, herbicides (weed killers) are most widely used(Japanese Journal of Crop Science, 2004; Geneva:WHO; 2006). The use of pesticides therefore continues to exist as world population and the demand for food production continues to grow., Pesticides are a public health concern and have been linked to a range of diseases and disorders. Although pesticides play a significant role in increasing food production, exposure to pesticides can be harmful to humans(Graeme, 2007; Goto,2003; Gilden et al., 2010). The ill-effects may follow from short or long term exposure and from low-or high level exposure through skin contact, inhalation, or indigestion. Some pesticides are highly toxic, with a few drops causing extremely harmful effects. Some other pesticides are less toxic and too much exposure of them can cause harmful effects.

The present study aimed toinvestigate and quantify the residues of some commonly used pesticides on selected vegetables grown in selected areas of Pathanamthitta district.

\section{Study Area}

Pathanamthitta is a town and a municipality situated in central Travancore region in the state of Kerala, south India, spreading over an area of $23.50 \mathrm{~km}^{2}$. The town has a population of 38,000 . Pathanamthitta is a landlocked district bordered by Kottayam and Idukki districts in the north, Alappuzha district in the west, Kollam district in the south and Tamil Nadu state in the east. Average annual temperature of the area ranges from $20{ }^{\circ} \mathrm{C}$ to $39^{\circ} \mathrm{C}$. The district experiences distinct weather conditions such as winter (December to February), summer (March to May) and the monsoon. The monsoons include south-west (June to September) and north-east (October to November). About 75 percent of the annual rainfall is received during south-west monsoon. The areas such as Naranamuzhy, Vechoochira and RanniPanchayatsinPathnamthitta district are considered for the present study.

Agriculture is the main occupation of the people. About $75 \%$ people are dependent on this sector. Rubber is the most important crop followed by vegetables such as snake gourd,brinjal, tomato, cucumber, bitter gourd, pea and plantain. The Pambariver (176 km long), the third longest river in kerala, flowing through the study area, forms a major source of irrigation. Though farmers use farm chemicals, quite a good majority still depend on synthetic pesticides for pest management in the soil.

\section{Materials and Methods}

The present study concerns about the pesticide consumption and use pattern in major vegetable tracks of Kollamdistrict, to assess the pesticide residues in major vegetable farm gate.

\subsection{Questionnaire Survey}

A detailed questionnaire survey was conducted in the vegetable tracks of Pathnamthittadistrict.to identify type, frequency of application and amount of pesticides used. Almost 50 farmers were interviewed and their response was used to create a data base on pesticide used pattern of the vegetable tracks.

\subsection{Sample collection}

$>\quad$ Fresh samples of vegetables were randomly collected from each replicate to assess the residue level of pesticide applied during the month of August 2011 
Edible portions of the vegetables were sampled and immediately transported to laboratory in plastic bags after collection. The samples were stored in $-20^{\circ} \mathrm{C}$ using laboratory freezer inorder to avoid any degradation between sampling and analysis. The extraction and clean up procedures were performed as modified QuEChERs method.

\subsection{Preparation of mixture of standard insecticides}

An analytical standard solution was prepared from Certified reference material. A weighed amount of analytical grade material was dissolved in distilled acetone and diluted with $n$-hexane: toluene (1:1) to obtain a1000 ppm stock solution. From this $10 \mathrm{ml}$ was taken and diluted to $100 \mathrm{ml}$ using distilled $\mathrm{n}$-hexane: toluene to obtain a 100ppm stock solution of each Insecticides. A working standard of 5ppm of the mixture was prepared and stored in refrigerator for further use. The individual standards of different insecticides were injected into Gas Liquid Chromatograph

\section{4 .Soil analysis}

Soil samples collected from the study area were analyzed for physico-chemical properties such as $\mathrm{pH}$, electrical conductivity, cation exchange capacity, texture, water holding capacity and soil nutrients. The soil $\mathrm{pH}$ was determined by $\mathrm{pH}$ meter with glass electrode (Jackson, 1973), electrical conductivity by Conductivity meter (Jackson, 1973), texture by International pipette method (Piper, 1966), water holding capacity by Undisturbed core sample (Black et al., (1965) and cation exchange capacity by Ammonium acetate method (Jackson, 1973). The soil nutrients analyzed for the study include organic carbon by Walkley and Black method (Jackson, 1973), Available nitrogen by Alkaline permanganate method (Subbiah and Asija, 1956), Available phosphorus and pottassium by spectrophotometry (Jackson, 1973), calcium and magnesium by EDTA method (Hesse, 1971), sulphur by Turbidimetry method (Chesnin and Yein, 1951).

\subsection{Extraction}

The vegetable samples were extracted using acetonitrile as solvent..QuEChERSmethodwasadopted. Vegetable were chopped with a sharp knife and mixedthroughly.The chopped sample were tranformed into a high speed blender.The samples were throughlyblended to obtain a homogeneous representative sample for weighing. 25 gmof.the sample was taken in an Erlenmeyer flask. To this add 4 gmagnesiumsulphate(hydrate $1 \mathrm{gm}$ sodium chloride and $1 \mathrm{gm}$ sodium citrate tribasic dehydrate were added. Then $20 \mathrm{ml}$ of acetonitrile was added and the samples were shaken for one minute in a vortex and centrifuged for 4 minutes at 4,000 rpm. A dispersive solid phase extraction clean-up process was carried out by transferring the supernatant $(10 \mathrm{ml})$ to a centrifuge tube $(15 \mathrm{ml})$ containing $1.5 \mathrm{gm}$ magnesium sulphate (hydrated) and $0.250 \mathrm{~g}$ PSA (Primary Secondary Amine) and was shaken for a few seconds followed by centrifugation at 4,400 rpm for 10 minutes. The cleaned supernatant extract was evaporated to dryness at $400 \mathrm{C}$ using turbovap. The dry residue was redissolved in $\mathrm{n}$ hexane and the volume was made upto $5 \mathrm{ml}$ and analysed in Gas Liquid Chromatograph.

\subsection{Estimation}

The cleaned extracts were anlaysed on a Gas Liquid Chromatograph (Shimadzu-2010) equipped with $63 \mathrm{Ni}$ Electron Capture Detector (ECD) fitted with capillary column (J \$ W, DB-5) of 30mx0.25 mm i.d xo. $25 \mu \mathrm{m}$ dimension. The sample was injected in a split mode with split ratio 1: 10. The injector and detector temperature was maintained at $2500 \mathrm{C}$ and $3000 \mathrm{C}$ respectively. The column temperature was programmed at $160^{\circ} \mathrm{C}$ to $270^{\circ} \mathrm{C}$ at the rate of $50^{\circ} \mathrm{C}$ per minute ( $8 \mathrm{~min}$ hold) The volume of sample injected was $2 \mu$ I. Ultra high purity (USP) nitrogen $(99.999 \%$ ) was used as carrier gas with flow rate of $1.06 \mathrm{ml} / \mathrm{min}$ and linear velocity of $26.0 \mathrm{~cm} / \mathrm{sec}$.

\section{Results And Discussion}

\subsection{Data base on pesticide use pattern in vegetable tracks of Kollam district.}

A detailed questionnaire survey was carried out in the study area and a database on pesticide use by the farmers was created. The analysis of the data showed that most of the farmers are in their old age and are adopting the management practices based on their own experience. Among the conventional insecticidesused,organophosphorus compounds like Phorate, Chlorpyriphos, Quinalphos, Methyl parathion, Triazophos, Profenophos and Ethion contribute the lion share. Majority of the farmers followed their own spraying schedules and doses of insecticides to control pests and diseases. It was observed that the spraying schedule went up to more than twenty four rounds of spraying with various chemicals in rotationThe results are shown in Table. 1

\subsection{Monitoring of pesticide residues in soil samples.}

In this study pesticide residues in vegetables were analysed to assess the status of residues. Vegetable samples were collected from the various locations and analysed for pesticides residues. Residues were not 
detected in any samples and it indicates that the vegetables are not contaminated due to pesticide spraying Table $2,3,4$. So the hazard due to pesticides usage is not a matter of concern in the vegetable ecosystem.

Table 1. Pesticide Use Pattern

\begin{tabular}{|c|c|c|c|c|}
\hline $\begin{array}{l}\text { Types of pesticides } \\
\text { used }\end{array}$ & $\begin{array}{l}\text { Frequency of } \\
\text { application }\end{array}$ & Dosage & Dose (ha) & Dose(L) \\
\hline Thimet & At the time of planting & & $8.3 \mathrm{~kg} \mathrm{ha}^{-1}$ & \\
\hline Curacron & 15-20 days interval & $\begin{array}{ccc}150 \mathrm{ml} & -300 & \mathrm{ml} \\
100 \mathrm{~L}^{-1} & & \end{array}$ & $\begin{array}{c}750 \mathrm{ml} \mathrm{ha}^{-1}-1.5 \mathrm{~L} \\
\mathrm{ha}^{-1}\end{array}$ & $1.5-3 \mathrm{ml} \mathrm{L}^{-1}$ \\
\hline Hilban & 20 - 25 days interval & $\begin{array}{l}150 \mathrm{ml}-300 \quad \mathrm{ml} \\
100 \mathrm{~L}^{-1}\end{array}$ & ${ }_{1}^{750} \mathrm{ml}$ ha- $1.5 \mathrm{~L} \mathrm{ha}^{-}$ & $1.5 \mathrm{ml}-3 \mathrm{ml} \mathrm{L}^{-1}$ \\
\hline Ekalux, Hilquin & 25 days interval & $200 \mathrm{ml} \mathrm{100L}^{-1}$ & $1 \mathrm{~L} \mathrm{ha}^{-1}$ & $2 \mathrm{ml} \mathrm{L}^{-1}$ \\
\hline Hostathion, Josh & 25 days interval & $200{\mathrm{ml} 100 \mathrm{~L}^{-1}}^{-1}$ & $1 \mathrm{~L} \mathrm{ha}^{-1}$ & $2 \mathrm{ml} \mathrm{L}^{-1}$ \\
\hline Monocil, Nuvacron & 25 days interval & $200-250{\mathrm{ml} 100 \mathrm{~L}^{-1}}^{-1}$ & $1 \mathrm{~L}-1.25 \mathrm{~L} \mathrm{ha}^{-1}$ & $\begin{array}{l}2 \mathrm{ml} \mathrm{L}^{-1}-2.5 \mathrm{ml} \\
\mathrm{L}^{-1}\end{array}$ \\
\hline Metacid & 15-20 days interval & $200{\mathrm{ml} 100 \mathrm{~L}^{-1}}^{-1}$ & $1 \mathrm{~L} \mathrm{ha}^{-1}$ & $2 \mathrm{ml} \mathrm{L}^{-1}$ \\
\hline Viraat & 20 days interval & $300{\mathrm{ml} 100 \mathrm{~L}^{-1}}^{-1}$ & $1.5 \mathrm{~L} \mathrm{ha}^{-1}$ & $3 \mathrm{ml} \mathrm{L}^{-1}$ \\
\hline Avaunt & 30 days interval & $30 \mathrm{ml} \mathrm{100 \textrm {L } ^ { - 1 }}$ & $150 \mathrm{ml} \mathrm{ha}^{-1}$ & $0.03 \mathrm{ml} \mathrm{L}^{-1}$ \\
\hline Spark & 22 days interval & $75-100 \mathrm{ml}^{100 \mathrm{~L}^{-1}}$ & $0.37 \mathrm{~L} \mathrm{ha}^{-1}$ & $0.75-1 \mathrm{ml} \mathrm{L}^{-1}$ \\
\hline Karate & 15 - 20 days interval & 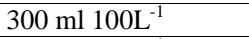 & $1.5 \mathrm{~L} \mathrm{ha}^{-1}$ & $3 \mathrm{ml} \mathrm{L}^{-1}$ \\
\hline Shakti & 22 days interval & $300 \mathrm{ml} \mathrm{100L}^{-1}$ & $1.5 \mathrm{~L} \mathrm{ha}^{-1}$ & $3 \mathrm{ml} \mathrm{L}^{-1}$ \\
\hline Koragen & Monthly & $10 \mathrm{ml} \mathrm{100L}^{-1}$ & $50 \mathrm{ml} \mathrm{ha}^{-1}$ & $0.01 \mathrm{ml} \mathrm{L}^{-1}$ \\
\hline Hilmida & 22 days interval & $200-300{\mathrm{ml} 100 \mathrm{~L}^{-1}}^{-1}$ & $1-1.5 \mathrm{~L} \mathrm{ha}^{-1}$ & $2-3 \mathrm{ml} \mathrm{L}^{-1}$ \\
\hline Titan & 22 days interval & $300 \mathrm{ml}^{100 \mathrm{~L}^{-1}}$ & $1.5 \mathrm{~L} / \mathrm{ha}$ & $3 \mathrm{ml} \mathrm{L}^{-1}$ \\
\hline Spark & 22 days interval & $100-300 \mathrm{ml}^{100 \mathrm{~L}^{-1}}$ & $500 \mathrm{ml}-1.5 \mathrm{Lha}^{-1}$ & $1-3 \mathrm{ml} \mathrm{L}^{-1}$ \\
\hline Josh & 22 days interval & $300 \mathrm{ml}^{100 \mathrm{~L}^{-1}}$ & $1.5 \mathrm{~L} \mathrm{ha}^{-1}$ & $3 \mathrm{ml} \mathrm{L}^{-1}$ \\
\hline
\end{tabular}

Table.2 Pesticide analysis in Naranamuzhy

\begin{tabular}{|l|c|c|c|c|}
\hline \multirow{2}{*}{ Pesticides } & \multicolumn{4}{|c|}{ Vegetables } \\
\cline { 2 - 5 } & Pea & $\begin{array}{c}\text { Snake } \\
\text { Gourd }\end{array}$ & $\begin{array}{c}\text { Bitter } \\
\text { Gourd }\end{array}$ & Brinjal \\
\hline Chlorpyriphos & ND & ND & ND & ND \\
\hline $\begin{array}{l}\text { Methyl Para } \\
\text { Thion }\end{array}$ & ND & ND & ND & ND \\
\hline Phorate & ND & ND & ND & ND \\
\hline Ethion & ND & ND & ND & ND \\
\hline DDT & ND & ND & ND & ND \\
\hline Endosulphan & ND & ND & ND & ND \\
\hline
\end{tabular}

Table.3. Pesticide analysis in Vechoochira

\begin{tabular}{|l|c|c|c|c|}
\hline \multirow{2}{*}{\multicolumn{1}{|c|}{ Pesticides }} & \multicolumn{4}{|c|}{ Vegetables } \\
\cline { 2 - 5 } & Pea & $\begin{array}{c}\text { Snake } \\
\text { Gourd }\end{array}$ & $\begin{array}{c}\text { Bitter } \\
\text { Gourd }\end{array}$ & Brinjal \\
\hline Chlorpyriphos & ND & ND & ND & ND \\
\hline $\begin{array}{l}\text { Methyl Para } \\
\text { Thion }\end{array}$ & ND & ND & ND & ND \\
\hline Phorate & ND & ND & ND & ND \\
\hline Ethion & ND & ND & ND & ND \\
\hline DDT & ND & ND & ND & ND \\
\hline Endosulphan & ND & ND & ND & ND \\
\hline
\end{tabular}

Table 4 Pesticides detected in Ranni.

\begin{tabular}{|l|l|l|l|l|}
\hline \multirow{2}{*}{ Pesticides } & \multicolumn{4}{|l|}{ Vegetables } \\
\cline { 2 - 5 } & Pea & $\begin{array}{l}\text { Snake } \\
\text { Gourd }\end{array}$ & $\begin{array}{l}\text { Bitter } \\
\text { Gourd }\end{array}$ & Brinjal \\
\hline Chlorpyriphos & ND & ND & ND & ND \\
\hline $\begin{array}{l}\text { Methyl Para } \\
\text { Thion }\end{array}$ & ND & ND & ND & ND \\
\hline Phorate & ND & ND & ND & ND \\
\hline Ethion & ND & ND & ND & ND \\
\hline DDT & ND & ND & ND & ND \\
\hline Endosulphan & ND & ND & ND & ND \\
\hline
\end{tabular}




\subsection{Physico chemical properties of soil}

The physico chemical properties of samples from the three locations were analyzed and observed that they were very rich in organic carbon content and contains higher percentage of organic matter. The $\mathrm{pH}(6.24 \sim$ 6.90) of the study area is observed as neutral. The electrical conductivity ranges from 0.145 to $0.298 \mathrm{dSm}-1$, nitrogen content ranges from 387 to $712 \mathrm{kgha}-1$, phosphorus ranges from 63 to $114 \mathrm{kgha}-1$, potassium ranges from 702 to 801 kgha-1, sulphur rangesfrom 19 to 42 kgha-1, organic carbon content ranges from 2.21 to 2.31 $\%$, organic matter ranges from 3.67 to 3.89 , exchangable calcium ranges from 1.72 to $1.78 \%$ and exchangable magnesium ranges from 1.12 to 1.33 . An average of $44 \%$ water holding capacity is observed in allsoils. The results revealed that the area is highly suitable for agriculture.

Table 5 Physico chemical properties of soil

\begin{tabular}{|l|l|l|l|}
\hline Properties & Naranamuzhy & Vechoochira & Ranni \\
\hline $\mathrm{pH}$ & 6.24 & 6.72 & 6.90 \\
\hline EC $\left(\mathrm{dSm}^{-1}\right)$ & 0.298 & 0.145 & 0.273 \\
\hline Available $\mathrm{N}\left(\mathrm{kg} \mathrm{ha}^{-1}\right)$ & 386.91 & 684.56 & 712.46 \\
\hline Available $\mathrm{P}\left(\mathrm{kg} \mathrm{ha}^{-1}\right)$ & 113.98 & 104.75 & 62.70 \\
\hline Available $\mathrm{K}\left(\mathrm{kg} \mathrm{ha}^{-1}\right)$ & 759.80 & 702.06 & 801.20 \\
\hline Available S $\left(\mathrm{kg} \mathrm{ha}^{-1}\right)$ & 19.66 & 42.06 & 19.88 \\
\hline Organic C $(\%)$ & 2.31 & 2.30 & 2.21 \\
\hline Organic matter & 3.67 & 3.89 & 3.73 \\
\hline Exchangeable Ca & 1.76 & 1.72 & 1.78 \\
\hline Exchangeable $\mathrm{Mg}$ & 1.33 & 1.17 & 1.12 \\
\hline Water holding capacity $(\%)$ & 45.74 & 46.40 & 42.06 \\
\hline
\end{tabular}

\section{4 .Physico chemical properties of water}

When water samples were analysed it was found that the $\mathrm{pH}$ was neutral

Table .6.Physico chemical properties of water

\begin{tabular}{|l|l|}
\hline pH & 6.85 \\
\hline BOD & 2.0 \\
\hline COD & 62.4 \\
\hline
\end{tabular}

\section{Conclusion}

In this study, a detailed analysis of were carried out to study the impact of pesticides on vegetables. The questionnaire survey revealed the excessive use of pesticides in the study area. The physico-chemical analysis of the soil samples showed that the area is highly suitable for agriculture. The pesticide residues were not detected in any of the sample The water sample analysis revealed that presently the water was not contaminated with pesticides. The study therefore showed that, if the use of pesticides continues the concentration of pesticide residues in soil and water may increase, which can harm the flora and fauna of the area. This raises concern and needs immediate management policies to be adopted in the study area.

\section{Acknowledgements}

The authors thank Kerala Agricultural University and CEPC, Kollam for allowing to carry out analysis.

\section{References}

[1] Graeme, E. Batley, Graeme.batley@csiro.au*, Centre for Environmental Contaminants Research, CSIRO Land andWater, Locked Bag 2007, Kirrawee, NSW 2232, Australia.

[2] Goto, Collin S. 2003. Heavy Metal Intoxication. In: NelsonTextbook of Pediatrics, 17th ed. Edited by Richard E.Behrman, et al. Philadelphia: Saunders, pp. 2355-71.

[3] Gilden RC, Huffling K, Sattler, B. 2010. Pesticides and Healthrisks.JObstetGynecol Neonatal Nurs. 39 (1) : $103-110$

[4] Jackson, M. L., (1973). Soil chemical analysis: Advanced Course (2nd edition)

[5] Piper.(1966), ,C.S.Soil and Plant Analysis, Hani Publishers,Bombay

[6] Black. C. A, (1965). Methods of Soil Analysis, Part I and II, Am. Soc. Agron: Madison, Wiscosis, ,

[7] Subbiah B. V. and Asija G.L., (1956) A rapid procedure for estimation of available nitrogen in soils. Curr.Sci. 25259-260.

[8] Hesse, (1971) Particle size distribution in gypsicsoils,plants and soil 241-247

[9] Chesnin and Yein,(1951), Turbidometricditermination of avialable sulphates, SoilSci. Am.soc.Proc.14149-151.

[10] F. J. Schenck and J. E. Hobbs. (2004) Evaluation of the Quick, Easy, Cheap, Effective, Rugged, and Safe (QuEChERS) Approach to Pesticide Residue Analysis. Bulletin of Environmental Contamination and Toxicology (New York: Springer), 73 (1) 24-30.

[11] Payá P, Anastassiades M, Mack D, et al. (2007). "Analysis of pesticide residues using the QuEChERSpesticidemultiresidue method in combination with gas and liquid chromatography and tandem mass spectrometric detection". (389)61697-714.

[12] R.A.Issac and J.D.Kerber, R. 1971 A."Atomic absorption and flame photometry techniques and uses in soil, plant, and water anlysis."in Instrumental Methods for Analysis of Soils and Plant Tissue,L.M.Walsh, Ed. Soil Sceience Society of America, Madison, Wis, USA,. ,pp17-37.

[13] Pingali, Prabhu and Roger, Pierre.(1995).. Impact of Pesticides on Farmer Health and the Rice Environment. Norwell, Massachusetts, Kluwer Academic Publishers 
[14] AH.C.Robers, M.A.Turner and J.K.Syers:(1976). Analyst Simulltaneous Extraction of Cadmium and Zinc from soil Extracts.(101)574-578

[15] Graebing.P.Frank.M and Chib.J.S:(2002) .Effects of fertilizer and soil components on pesticide photolysis.J. Agri. Food. Chem. 507332-7339.

[16] J.A.OhayoMitoko(1997),PhDThesispp 254

[17] M.Bhanti.A.Taneja(2005).Monitoringoforganochlorine pesticides residues in summer and winter vegetables from Agra, India- a case study. Environmental monitoringandAssessment.110.341 